\title{
Estimating Availability of Logging Residues Using Forest Man- agement Records at Aggregated Stands of Nasushiobara City in Tochigi Prefecture, Japan
}

\author{
Ryo Uemura $^{1}$, Kazuhiro Aruga ${ }^{1 *}$, Kanae Kanetsuki $^{2}$
}

\begin{abstract}
Using forest management records from 2005 to 2010, this study compared supply potentials and available logging residue amounts from profitable aggregated stands in Nasushiobara city in Tochigi prefecture with those from profitable subcompartments. Supply potentials from precommercial, commercial thinning, and final felling operations were 39,584 tons, 10,376 tons, and 3,385 tons, respectively. Available amounts at $3,000,6,000$, and 10,000 yen/ton were estimated to be 2,920 tons, 3,495 tons, and 13,334 tons from profitable subcompartments and 2,628 tons, 5,143 tons, and 29,940 tons from profitable aggregated stands, respectively. The available logging residue amounts were increased according to logging residue prices and for aggregated stands. Considering the subsidy, available amounts at $3,000,6,000$, and 10,000 yen/ton were increased to 20,526 tons, 34,981 tons, and 45,175 tons, respectively. The annual available logging residue amounts with a 3,000-yen/ton logging residue price were 3,421 tons/year over the expected demand of logging residues of 2,000 tons/year. Furthermore, the annual available logging residue amounts with a 6,000-yen/ton and a 10,000-yen/ton logging residue price were 5,830 tons/year and 7,529 tons/year over the expected demand for woody biomass of 5,000 tons/year. The supply potential and availability of logging residues, particularly from precommercial thinning operations, were significantly increased from 2009 because of the new tax that started in April 2008.
\end{abstract}

Keywords: available amount, forest management record, logging residue, subsidy, supply potential

\section{Introduction}

Japan depends on the import of oil, coal, and natural gas for the majority of its energy supply. The country's energy self-sufficiency rate in 2010 was just 5\% (Forestry Agency, The Ministry of Agriculture, Forestry and Fisheries of Japan, 2013). To secure a stable supply of energy, alternatives to fossil fuel, such as "renewable energy" including solar, wind, rivers, geothermal heat, and biomass, need to be developed. Among various biomass resources in Japan, woody biomass in particular attracts attention, not just because of its abundance but also because its energy use is expected to contribute to revitalizing forests and forestry product industries, which have been depressed for the last 30 years. Maintaining the relevant ecological, economic, and social functions of man-made forests, which are behind in tending, is also important.

In July 2011, the "Feed-in Tariff (FIT) Scheme for Renewable Energy Use" was introduced in accordance with new legislation entitled the "Act on Purchase of Renewable Energy Sourced Electricity by Electric Utilities." Under the FIT program, electricity generated from woody biomass is to be procured for 20 years at a fixed price (without tax) for unused materials such as logging residue: $32 \mathrm{yen} / \mathrm{kWh}$, general materials such as sawmill residue: $24 \mathrm{yen} / \mathrm{kWh}$, and recycled materials such as construction waste wood: 13 yen/kWh (Agency for Natural Resources and Energy, 2012). Power generated from unused materials is offered incentives, which is expected to promote the use of logging residue in the near future.

The Tochigi prefecture contains facilities such as biomass power plants, chip production factories, and pellet plants that require woody biomass resources. To examine the availability of woody biomass resources, the annual supply potential and availability of timber and logging residue from profitable subcompartments for all cities and towns in Tochigi prefecture were estimated using 2008 forest management records (Yamaguchi et al., 2014a, 2014b). In this study, estimations were conducted on the basis of subcompartments that were normal operation units in Japan. However, some forest owners' cooperatives aggregated subcompartments, established road networks, and promoted mechanization of aggregated stands to improve operational efficiency and reduce operation costs.

Therefore, Uemura et al. (2013) investigated stands aggregated with subcompartments in the Takahara area of Tochigi prefecture using subsidy applications and 2008 forest management records.

Received Aug.2, 2014; Accepted Jan.5, 2015; J-STAGE Advance Published Date : Feb. 20,2015

${ }^{1}$ Faculty of Agriculture, Utsunomiya University, Japan,

${ }^{2}$ Nasunogahara Land Improvement Districts, Japan

*Corresponding Author:aruga@cc.utsunomiya-u.ac.jp 
Then, the annual availability of timber and logging residue for aggregated stands was estimated as the annual supply potential from profitable stands, which was then compared with those for subcompartments. The results showed that operation costs were reduced and the annual availability of timber was increased from subcompartments to aggregated stands, whereas the annual availability of logging residues remained the same. Then, the system to aggregate neighboring subcompartments was developed. The results showed that the number and areas of stands aggregated by the system were similar to those of actual aggregated stands. Therefore, the operation costs and annual availability of timber and logging residue estimated by the system were also similar to those of actual aggregated stands.

This study first examined the system to aggregate neighboring subcompatments and compared the supply potential and availability of logging residue from profitable stands with those for subcompartments in Nasushiobara city in Tochigi Prefecture, where an agrarian organization was willing to conduct thinning operations and extract thinned wood for biomass power generation in cooperation with the Forest Owners' Co-operative (Aruga et al., 2013b). This supply potential and availability were estimated using forest management records for several fiscal years between 2005 and 2010 to examine the trends, particularly, with a new tax -Tochigi no genkina moridukuri kenmin zei-to make forests healthy, along with subsidies for thinning operations, that started in April 2008 (Tochigi Prefectural Government, 2010a).

\section{Study Site and Data}

The study site was Nasushiobara city in Tochigi Prefecture, Japan (Figure 1), with a gross area of $59,282 \mathrm{ha}$, and forest area of 37,433 ha (63\% of the gross area). The national forest and privately held and local government forest areas were 23,726 ha and 13,707 ha, respectively. In this study, major plantation species, such as Japanese cedar (Cryptomeria japonica) and Japanese cypress (Chamaecyparis obtuse) owned by private individuals and local governments, were analyzed. Private individuals and local governments owned 7,360 subcompartments of Japanese cedar comprising 2,855 ha, and 2,521 subcompartments of Japanese cypress comprising 1,103 ha. These forests are primarily 45 to 55 years old. The northern parts of Nasushiobara are mountainous; however, these areas are comprised mostly of national forests. Private and local government forests are located on relatively gentle slopes; therefore, the average slope angle is relatively low (17.6\%) and the forest road network density is relatively high $(27 \mathrm{~m} / \mathrm{ha})$.

Forest-registration data (stand ages, tree species, and site indices) and GIS data (information on roads and subcompartment layers) from the Tochigi Prefectural Government were used in the study, as were 10-m-grid digital elevation models (DEMs) from the Geographical Survey Institute. Private individuals and local governments own 6,342 subcompartments of Japanese cedar comprising 2,464 ha and 1,862 subcompartments of Japanese cypress comprising 839 ha, based on combined forest registration and GIS data. These numbers and subcompartment areas were $17 \%$ less than those of the actual subcompartments because of the relational problem between forest registration data and GIS data.

We used forest management records from 2005 to 2010 that were established from subsidy records. Therefore, final felling operations without a subsidy were not in the records. In this study, planting operations were assumed to occur the year after the final felling operations. Precommercial and commercial thinning operations, and final felling operations, were conducted on 1,004 subcompartments, 496 subcompartments, and 67 subcompartments of forest management records, respectively. However, only 894 subcompartments, 452 subcompartments, and 37 subcompartments were combined with forest registration data and GIS data (Table 1, Figure 2).

Because forests are almost 45 to 55 years old, many thinning operations were conducted and very few final felling operations were conducted (Figure 3) because of the low profitability of such operations with regeneration expenses on the current Japanese forestry situation (Aruga et al., 2013b). Given delays in thinning operations - a serious problem for man-made forests in Japan - in April 2008, the Tochigi Prefectural Government introduced the new tax. As a result, precommercial thinning operations increased significantly from 2009 (Figure 2). 


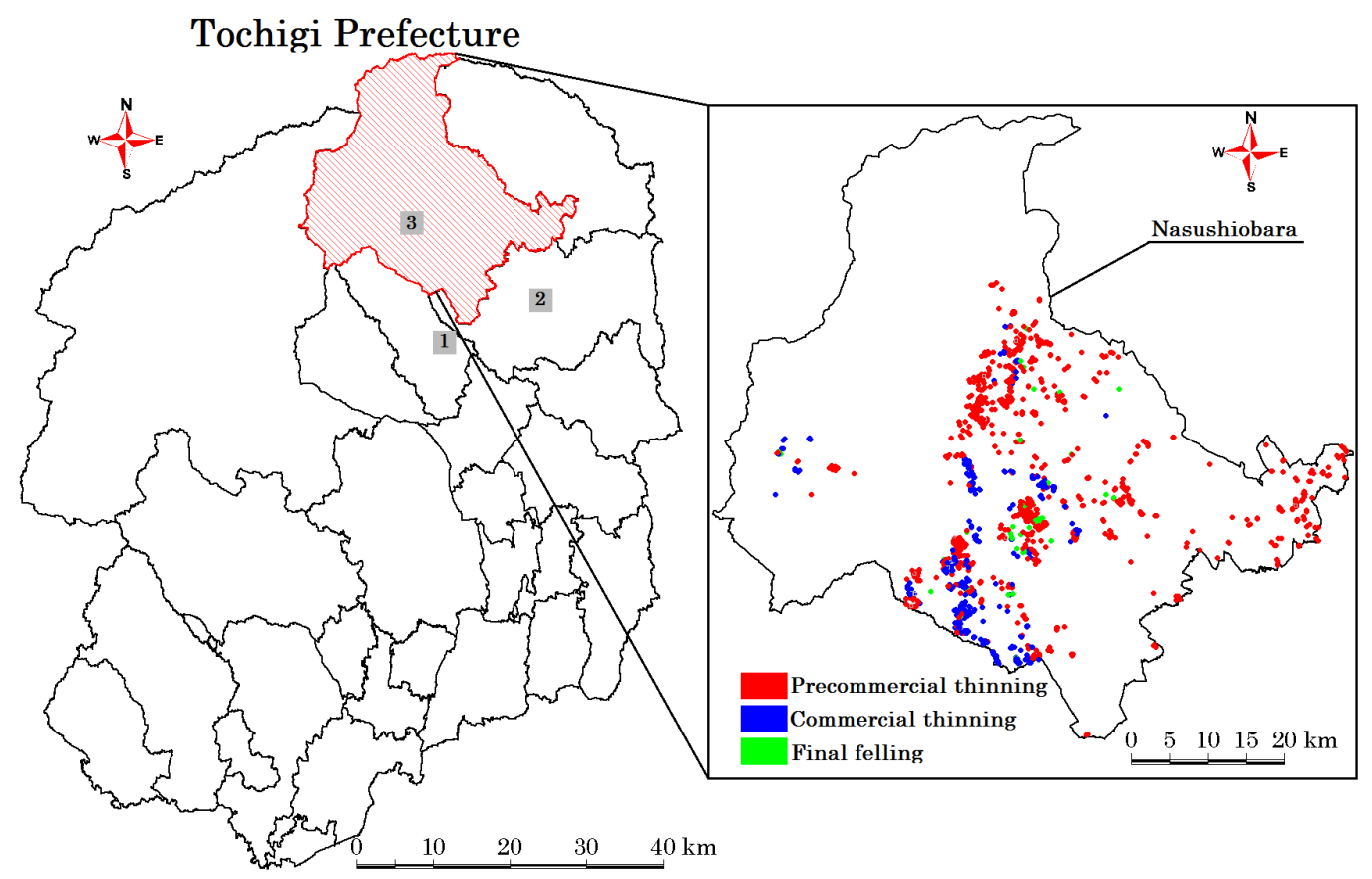

Figure 1. Distribution map of operation sites, log markets, and a plant (1: Yaita log market, 2: Ootawara log market, 3: A planed woody biomass power generation plant) (the points were magnified ten times to make them easier to see)

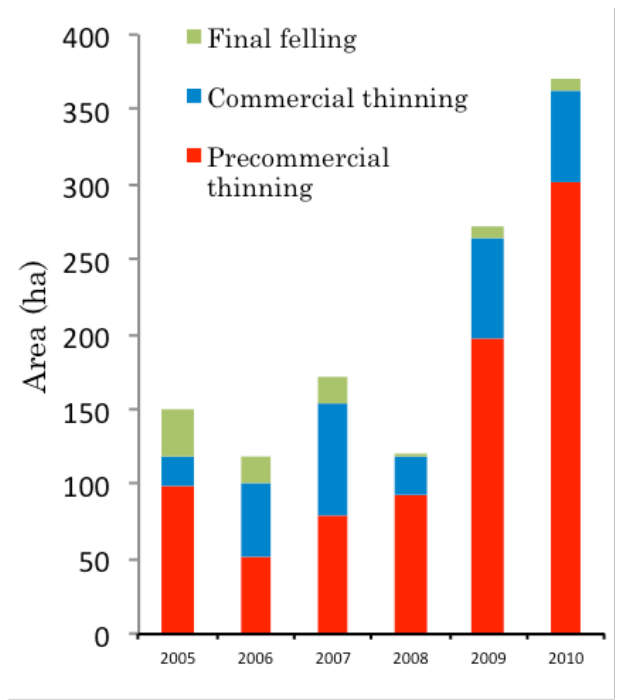

Figure 2. Operation site areas from 2005 to 2010. 
Table 1. The number and areas of subcompartments and supply potentials of timber and logging residues from 2005 to 2010.

\begin{tabular}{|c|c|c|c|c|c|c|c|c|}
\hline \multirow[b]{2}{*}{ Precommercial thinning } & \multicolumn{2}{|c|}{$\begin{array}{c}\text { No. } \\
\text { subcompartments }\end{array}$} & \multicolumn{2}{|c|}{$\begin{array}{c}\text { Area of } \\
\text { subcompartments }\end{array}$} & \multicolumn{2}{|c|}{$\begin{array}{c}\text { Supply } \\
\text { potentials of timber }\end{array}$} & \multicolumn{2}{|c|}{$\begin{array}{l}\text { Supply potentials } \\
\text { of logging residues }\end{array}$} \\
\hline & 894 & $64.64 \%$ & 820 ha & $68.38 \%$ & $5,161 \mathrm{~m}^{3}$ & $17.44 \%$ & 39,584 ton & $74.20 \%$ \\
\hline Commercial thinning & 452 & $32.68 \%$ & 298 ha & $24.82 \%$ & $12,375 \mathrm{~m}^{3}$ & $41.83 \%$ & 10,376 ton & $19.45 \%$ \\
\hline Final felling & 37 & $2.68 \%$ & 82 ha & $6.80 \%$ & $12,051 \mathrm{~m}^{3}$ & $40.73 \%$ & 3,385 ton & $6.35 \%$ \\
\hline Total & 1,383 & $100.00 \%$ & 1,200 ha & $100.00 \%$ & $29,587 \mathrm{~m}^{3}$ & $100.00 \%$ & 53,345 ton & $100.00 \%$ \\
\hline
\end{tabular}

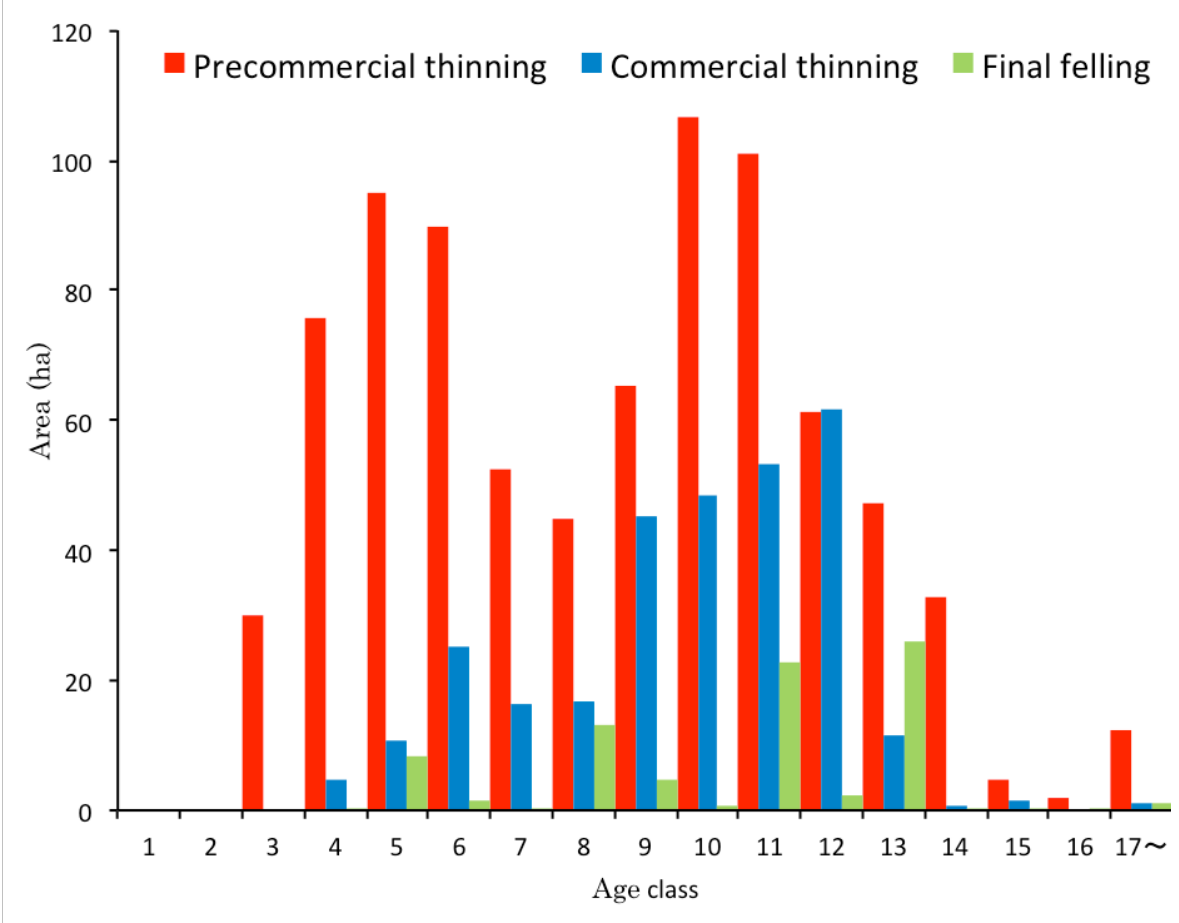

Figure 3. Frequency distribution of operation site areas from 2005 to 2010.

\section{Methods}

In this study, available logging residue amounts were projected in the following order: 1) the system aggregated neighboring subcompartments; 2) supply potentials were estimated on the basis of cutting and extraction rates; 3) forwarding and transportation distances were estimated; 4) total expenses for thinning and final felling operations for each operation system were estimated; 5) incomes were estimated without or with a subsidy; 6) profitability was estimated; and 7) available amounts were projected as supply potentials from profitable stands. Full technical details will be found in earlier papers (Yamaguchi et al., 2014a; Uemura et al., 2013).

The system aggregated adjacent subcompartments. As a result, 1,383 subcompartments were aggregated to 560 aggregated stands. The average area was increased from 0.87 ha for subcompartments to 2.14 ha for aggregated stands (Figure 4).

Estimation of the supply potential of timber and logging residue was based on the cutting rate $(C r)$, extraction rate $(E r)$, timber rate $(T r)$, and logging residue rate $(L r)$. The cutting rate $(C r)$ is $100 \%$ of the final felling operations and the thinning ratio of each subcompartment in the forest management records. The extracting rate $(E r)$, which is the ratio of the extracted volume to the felled tree volume (stocks of stems), was assumed to be $123 \%$ and $124 \%$ for Japanese cedar and 
Japanese cypress (Greenhouse Gas Inventory Office of Japan, 2006), respectively, considering branch extractions. The timber rate $(T r)$ is the ratio of the timber to be transported to $\log$ markets to the total felled and extracted tree volume, whereas the logging residue rate $(L r)$ is the ratio of the logging residue to be transported to the factories to the total felled and extracted tree volume. $\mathrm{Tr}$ and $\mathrm{Lr}$ are $10 \%$ and $90 \%$ of the stocks in precommercial thinning operations, respectively, both are $50 \%$ of the stocks in the commercial thinning operation, and $75 \%$ and $25 \%$ of the stocks in the final felling operations, respectively.

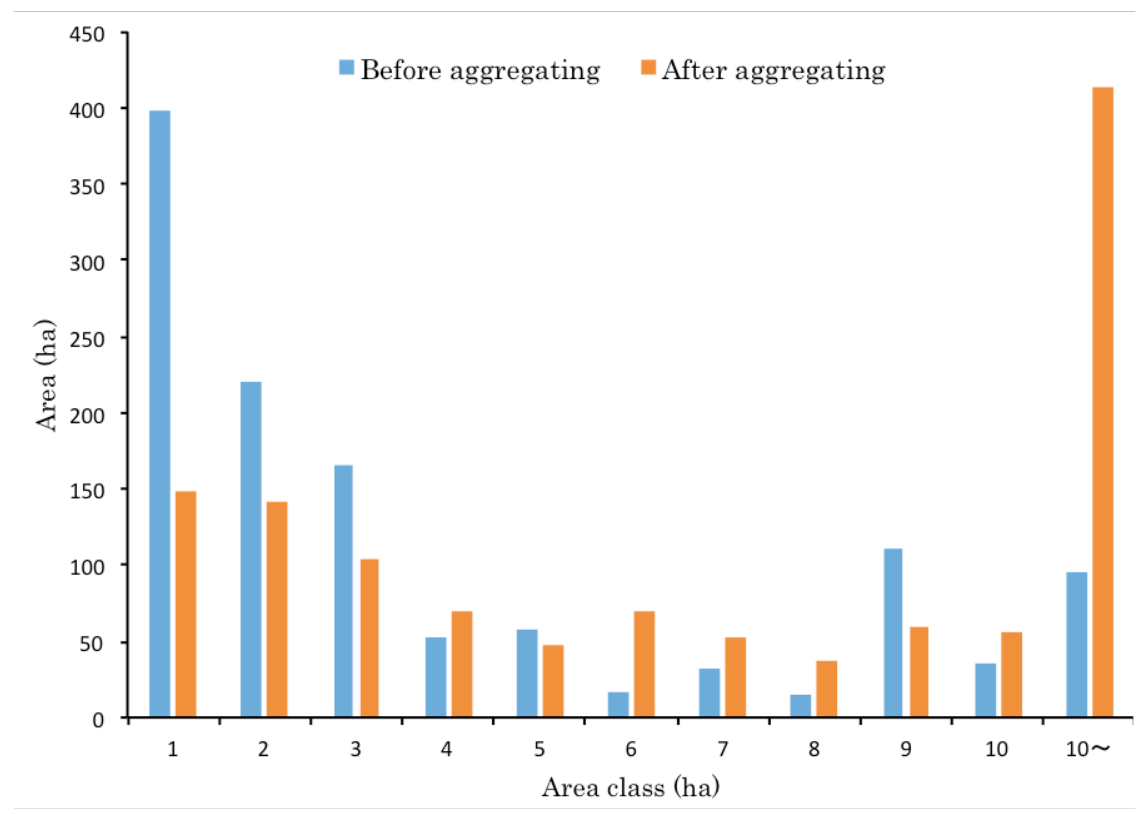

Figure 4. Areas before and after aggregating.

The supply potential of timber and logging residue was estimated by the following expressions.

$$
H=S \times C r \times E r=V \times A
$$

$$
\begin{aligned}
& H_{T}=H \times T r \\
& H_{L}=H \times L r \times G r
\end{aligned}
$$

$H$ is the extracted volume $\left(\mathrm{m}^{3}\right), S$ is the stock of the stems of a sub-compartment in the forest registration data $\left(\mathrm{m}^{3}\right), V$ is the extracted volume per hectare $\left(\mathrm{m}^{3} / \mathrm{ha}\right), A$ is area of subcompartments (ha), $H_{T}$ is the extracted timber volume $\left(\mathrm{m}^{3}\right), H_{L}$ is the extracted logging residues weight (ton), and $G r$ is the volume density, which is assumed to be $0.68 \mathrm{tons} / \mathrm{m}^{3}$ based on the Mikamo Forest Owners' Association survey results (2008).

Forwarding distances were estimated as the average distances from landings to all grids within the subcompartments. Landings were set within grids to minimize their distance from the roads, the centers of gravity in the sub-compartment, and a planned woody biomass power generation plant (Figure 1). Transportation distances from the landings to Yaita and Ootawara log markets and the plant were calculated by the shortest path algorithm, i.e., the Dijkstra method (Dijkstra, 1959). The plant needs 5,000 tons/year of woody biomass, of which 2,000 tons/year is expected from logging residues.

The direct and indirect operation expenses associated with each machine, and strip road and landing establishment expenses were estimated by the following equation.

$$
A=D+R+L+I
$$


where $A$ denotes all costs, $D$ is the direct operation expenses, $R$ is the strip-road-establishment expenses, $L$ is the landing-establishment expenses, and $I$ is the indirect operation expenses.

The direct expenses include labor and machinery expenses (maintenance, management, depreciation, and fuel and oil expenses). Machine transportation expenses, garage-maintenance expenses, overhead costs, handling fees associated with the log market, and consumption tax were considered as indirect operation expenses (Zenkoku Ringyo Kairyo Fukyu Kyokai, 2001).

The forest operation system was determined on the basis of interviews with forest owners' cooperative officials. The forest operation system included chainsaw felling and processing, grapple loader bunching, and forwarder forwarding. Only operations after chainsaw processing are considered in logging residue harvesting. In addition to the forest operation system, the forest operation system of the subcompartments on roads is assumed to consist only of piling by a grapple loader and transportation by a truck.

Revenue was estimated using supply potential and log prices for Japanese cedar and others $\left(10,000\right.$ yen $\left./ \mathrm{m}^{3}\right)$, Japanese cypress $\left(20,000\right.$ yen $\left./ \mathrm{m}^{3}\right)$, and logging residue (3,000 yen/ton). In addition, a logging residue price of 6,000 yen/ton was assumed with additional subsidies (Japanese Forestry Investigation Committee, 2011a), and a price of 10,000 yen/ton was assumed if FITs were introduced in Japan (Japanese Forestry Investigation Committee, 2011b).

For thinning operations, subsidies were received in Japan. Subsidies (Table 2) were estimated using standard unit costs, areas, assessment coefficients, and the subsidy rate of the Tochigi Prefectural Government (2010b). Standard unit costs were determined on the basis of ages and thinning rates. The assessment coefficient and the subsidy rate were assumed to be 1.7 and 4/10, respectively.

In Japan, subcompartments with subsidized thinning operations also received subsidies for the establishment of strip roads. Standard unit costs for the establishment of strip roads were determined using the average slope angle (degree) and the road width. Then, subsidies (Table 3) were estimated using standard unit costs, length, assessment coefficients, and the subsidy rate of Tochigi Prefectural Government (2010b). The assessment coefficient and the subsidy rate were assumed to be 1.7 and $4 / 10$, respectively.

After estimating the economic balances from revenue and costs, production forests were extracted as profitable stands. Then, the availability of timber and logging residues was estimated using the supply potential from the profitable stands.

Table 2. Subsidies for thinning operation (yen/ha).

\begin{tabular}{crrrrr}
\hline Thinning & \multicolumn{5}{c}{ Stand age (year) } \\
rate & -15 & $16-25$ & $26-35$ & $36-45$ & $46-60$ \\
\hline $20 \%-$ & 204,735 & 235,504 & 236,990 & 225,457 & 228,348 \\
$30 \%-$ & 307,788 & 352,910 & 355,145 & 338,188 & 342,520 \\
\hline
\end{tabular}

Table 3. Subsidies for strip road establishment (yen $/ \mathrm{m}$ ).

\begin{tabular}{crr}
\hline Average slope & \multicolumn{2}{c}{ Width } \\
angle & $2.5 \mathrm{~m}$ & $3.5 \mathrm{~m}$ \\
\hline Gradual (-15 degrees) & 102 & 153 \\
Medium (15-30 degrees) & 203 & 358 \\
Steep (30- degrees) & 501 & 1,262 \\
\hline
\end{tabular}

\section{Results and Discussions}

\subsection{Supply Potentials}

The supply potentials of timber and logging residue were $29,587 \mathrm{~m}^{3}$ and 53,345 tons $(8,890$ tons/year), of which $17 \%\left(5,161 \mathrm{~m}^{3}\right)$ and $74 \%$ (39,584 tons or 6,597 tons/year) were from precommercial thinning operations, $42 \%\left(12,375 \mathrm{~m}^{3}\right)$ and $19 \%(10,376$ tons or 1,729 tons/year) were from 
commercial thinning operations, and $41 \%\left(12,051 \mathrm{~m}^{3}\right)$ and $6 \%(3,385$ tons or 564 tons/year) were from final felling operations, respectively (Table 1, Figure 5).

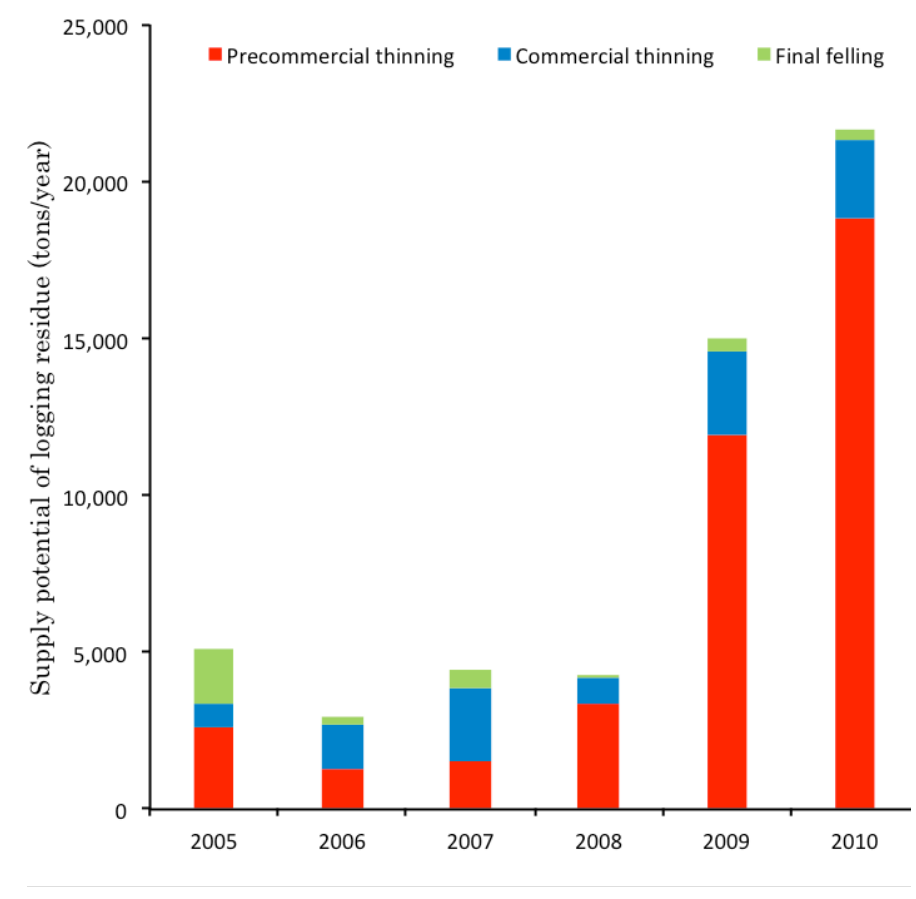

Figure 5. Supply potentials of logging residues from 2005 to 2010.

\subsection{Available Amounts from Profitable Subcompartments without Subsidy}

The number and areas of profitable subcompartments with a 3,000-yen/ton logging residue price were 19 subcompartments $(1.37 \%)$ and 63 ha $(5.28 \%)$, of which 0 subcompartments $(0.00 \%)$ and 0 ha $(0.00 \%)$ were from precommercial thinning operations, 7 subcompartments $(1.55 \%)$ and 8 ha $(2.79 \%)$ were from commercial thinning operations, and 12 subcompartments $(32.43 \%)$ and 55 ha $(67.45 \%)$ were from final felling operations, respectively (Table 4). No precommercial thinning operations were profitable. Almost all profitable subcompartments were from final felling operations. Therefore, the available timber and logging residue amounts from profitable subcompartments with a 3,000-yen/ton logging residue price were $9,991 \mathrm{~m}^{3}$ and 2,920 tons (487 tons/year), of which $0 \%$ (0 $\mathrm{m}^{3}$ ) and $0 \%$ (0 tons or 0 tons/year) were from precommercial thinning operations, $2 \%\left(237 \mathrm{~m}^{3}\right)$ and $7 \%$ (200 tons or 33 tons/year) were from commercial thinning operations, and $98 \%\left(9,754 \mathrm{~m}^{3}\right)$ and 93\% (2,721 tons or 454 tons/year) were from final felling operations, respectively (Tables 5 and 6 , Figure 6). The supply potential of logging residues from precommercial thinning operations occupied $74 \%$. However, no available logging residue amount from precommercial thinning operations were estimated and almost all available logging residue amounts were from final felling operations because of profitability (Table 7). The number and areas of profitable subcompartmetns and available logging residue amounts were increased according to logging residue prices (Tables 4 and 6). In particular, the logging residue amount from precommercial thinning operations was significantly increased with a 10,000-yen/ton logging residue price from 2008 because the new tax started in April 2008 (Figure $6)$. 
Table 4. The number and areas of profitable subcompartments without subsidy from 2005 to 2010.

\begin{tabular}{|c|c|c|c|c|c|c|c|c|c|c|c|c|}
\hline \multirow[t]{2}{*}{ Unit prices } & \multicolumn{4}{|c|}{3,000 yen/ton } & \multicolumn{4}{|c|}{6,000 yen/ton } & \multicolumn{4}{|c|}{10,000 yen/ton } \\
\hline & No. & $\begin{array}{r}\text { Ratio } \\
(\%)\end{array}$ & $\begin{array}{c}\text { Area } \\
\text { (ha) }\end{array}$ & $\begin{array}{r}\text { Ratio } \\
(\%)\end{array}$ & No. & $\begin{array}{r}\text { Ratio } \\
(\%)\end{array}$ & $\begin{array}{c}\text { Area } \\
\text { (ha) }\end{array}$ & $\begin{array}{r}\text { Ratio } \\
(\%)\end{array}$ & No. & $\begin{array}{r}\text { Ratio } \\
(\%)\end{array}$ & $\begin{array}{c}\text { Area } \\
\text { (ha) }\end{array}$ & $\begin{array}{r}\text { Ratio } \\
(\%)\end{array}$ \\
\hline Precommercial thinning & 0 & 0.00 & 0 & 0.00 & 0 & 0.00 & 0 & 0.00 & 42 & 4.70 & 135 & 16.47 \\
\hline Commercial thinning & 7 & 1.55 & 8 & 2.79 & 18 & 3.98 & 16 & 5.33 & 45 & 9.96 & 47 & 15.61 \\
\hline Final felling & 12 & 32.43 & 55 & 67.45 & 20 & 54.05 & 67 & 82.33 & 25 & 67.57 & 71 & 86.37 \\
\hline Total & 19 & 1.37 & 63 & 5.28 & 38 & 2.75 & 83 & 6.93 & 112 & 8.10 & 252 & 21.01 \\
\hline
\end{tabular}

Table 5. Available amounts of timber and ratio to supply potentials on profitable sub-compartments without subsidy from 2005 to 2010 .

\begin{tabular}{lrrrrrr}
\hline Unit prices & \multicolumn{2}{c}{3,000 yen/ton } & \multicolumn{2}{c}{6,000 yen/ton } & \multicolumn{2}{c}{10,000 yen/ton } \\
& Amounts $\left(\mathrm{m}^{3}\right)$ & Ratio $(\%)$ & Amounts $\left(\mathrm{m}^{3}\right)$ & Ratio $(\%)$ & Amounts $\left(\mathrm{m}^{3}\right)$ & Ratio (\%) \\
\hline Precommercial thinning & 0 & 0.00 & 0 & 0.00 & 1,137 & 22.03 \\
Commercial thinning & 237 & 1.91 & 425 & 3.43 & 1,832 & 14.80 \\
Final felling & 9,754 & 80.94 & 11,197 & 92.91 & 11,549 & 95.83 \\
\hline Total & 9,991 & 33.77 & 11,622 & 39.28 & 14,517 & 49.07 \\
\hline
\end{tabular}

\subsection{Available Amounts from Profitable Aggregated Stands without Subsidy}

The number and areas of profitable aggregated stands with a 3,000-yen/ton logging residue price were 17 aggregated stands including 42 subcompartments (3.04\%) and 76 ha $(6.30 \%)$, of which 0 subcompartments $(0.00 \%)$ and 0 ha $(0.00 \%)$ were from precommercial thinning operations, 35 subcompartments $(7.74 \%)$ and 24 ha $(8.11 \%)$ were from commercial thinning operations, and 7 subcompartments $(18.92 \%)$ and 51 ha $(63.02 \%)$ were from final felling operations, respectively (Table 8). The available timber and logging residue amounts from profitable aggregated stands with a 3,000yen/ton logging residue price were $7,992 \mathrm{~m}^{3}$ and 2,628 tons (438 tons/year), of which $0 \%\left(0 \mathrm{~m}^{3}\right)$ and $0 \%$ (0 tons or 0 tons/year) were from precommercial thinning operations, $8 \%\left(634 \mathrm{~m}^{3}\right)$ and $20 \%$ (537 tons or 90 tons/year) were from commercial thinning operations, and $92 \%\left(7,359 \mathrm{~m}^{3}\right)$ and $80 \%$ (2,091 tons or 349 tons/year) were from final felling operations, respectively (Tables 9 and 10, Figure 7). The number and areas of profitable subcompartments and available logging residue amounts from commercial thinning operations were increased for aggregated stands. However, the number and areas of profitable subcompartments and available logging residue amounts from final felling

Table 6. Available amounts of logging residues and ratio to supply potentials on profitable subcompartments without subsidy from 2005 to 2010.

\begin{tabular}{|c|c|c|c|c|c|c|}
\hline \multirow[t]{2}{*}{ Unit prices } & \multicolumn{2}{|c|}{3,000 yen $/$ ton } & \multicolumn{2}{|c|}{6,000 yen/ton } & \multicolumn{2}{|c|}{10,000 yen/ton } \\
\hline & Amounts (ton) & Ratio (\%) & Amounts (ton) & Ratio (\%) & Amounts (ton) & Ratio $(\%)$ \\
\hline Precommercial thinning & 0 & 0.00 & 0 & 0.00 & 8,558 & 21.62 \\
\hline Commercial thinning & 200 & 1.93 & 358 & 3.45 & 1,536 & 14.80 \\
\hline Final felling & 2,721 & 80.38 & 3,137 & 92.67 & 3,240 & 95.72 \\
\hline Total & 2,920 & 5.47 & 3,495 & 6.55 & 13,334 & 25.00 \\
\hline
\end{tabular}

Table 7. Average economic balances $\left(\mathrm{yen} / \mathrm{m}^{3}\right)$.

\begin{tabular}{lrrrrrrrr}
\hline Unit prices & \multicolumn{3}{c}{$\begin{array}{c}\text { Subcompartment } \\
\text { without subsidy }\end{array}$} & \multicolumn{2}{c}{$\begin{array}{c}\text { Aggregated stand } \\
\text { without subsidy }\end{array}$} & \multicolumn{2}{c}{$\begin{array}{c}\text { Aggregated stand } \\
\text { with subsidy } \\
\end{array}$} & \multicolumn{2}{c}{ Revenues } & Cost & Balance & Revenues & Cost & Balance & Subsidy & Balance \\
& 2,850 & 13,955 & $-11,104$ & 2,905 & 9,966 & $-7,062$ & 4,410 & $-2,652$ \\
Precommercial thinning & 6,194 & 11,403 & $-5,210$ & 6,093 & 8,385 & $-2,292$ & 3,549 & 1,257 \\
Commercial thinning & 7,451 & 7,757 & -306 & 7,931 & 7,819 & 111 & 0 & 111 \\
Final felling & 4,506 & 12,224 & $-7,718$ & 4,506 & 9,227 & $-4,721$ & 3,500 & $-1,221$ \\
\hline Total & & & & & & & &
\end{tabular}




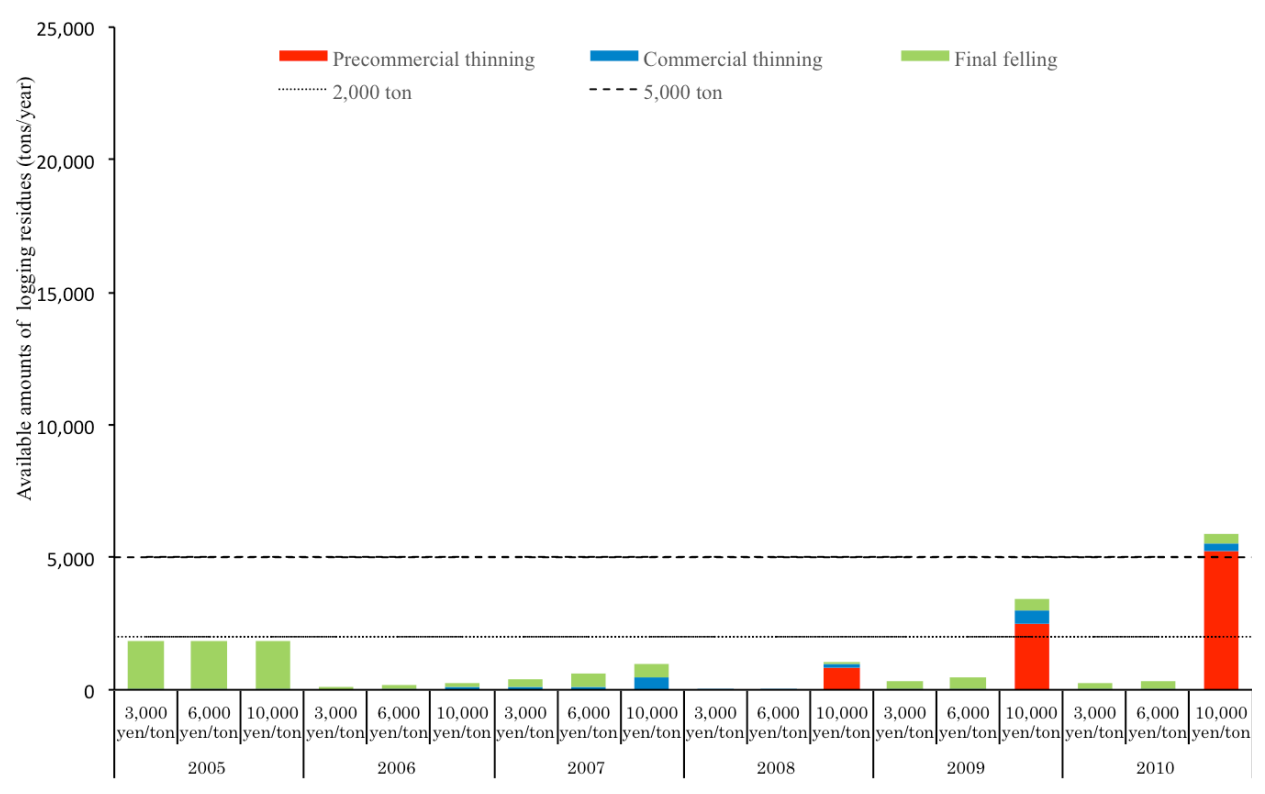

Figure 6. Available amounts of logging residues on profitable sub-compartments without subsidy from 2005 to 2010 .

operations were decreased because the profitability of these operations was reduced by aggregating the deficit thinning operations. Similar to subcompartments, the available logging residue amounts from profitable aggregated stands were increased according to logging residue prices. Increases in the available logging residue amounts from profitable aggregated stands were higher than those from profitable subcompartments. In particular, the available logging residue amounts from profitable aggregated stands with a 10,000-yen/ton logging residue price were more than double those for profitable subcompartments.

Table 8. The number and areas of profitable aggregated stands without subsidy from 2005 to 2010.

\begin{tabular}{|c|c|c|c|c|c|c|c|c|c|c|c|c|}
\hline \multirow[t]{2}{*}{ Unit prices } & \multicolumn{4}{|c|}{3,000 yen/ton } & \multicolumn{4}{|c|}{6,000 yen/ton } & \multicolumn{4}{|c|}{10,000 yen/ton } \\
\hline & No. & $\begin{array}{r}\text { Ratio } \\
(\%)\end{array}$ & $\begin{array}{r}\text { Area } \\
\text { (ha) }\end{array}$ & $\begin{array}{r}\text { Ratio } \\
(\%)\end{array}$ & No. & $\begin{array}{r}\text { Ratio } \\
(\%)\end{array}$ & $\begin{array}{r}\text { Area } \\
\text { (ha) }\end{array}$ & $\begin{array}{r}\text { Ratio } \\
(\%)\end{array}$ & No. & $\begin{array}{r}\text { Ratio } \\
(\%)\end{array}$ & $\begin{array}{c}\text { Area } \\
\text { (ha) }\end{array}$ & $\begin{array}{r}\text { Ratio } \\
(\%)\end{array}$ \\
\hline Stand & 17 & 3.04 & 76 & 6.30 & 34 & 6.07 & 144 & 12.02 & 134 & 23.93 & 697 & 58.03 \\
\hline Precommercial thinning & 0 & 0.00 & 0 & 0.00 & 0 & 0.00 & 0 & 0.00 & 239 & 26.73 & 399 & 48.57 \\
\hline Commercial thinning & 35 & 7.74 & 24 & 8.11 & 108 & 23.89 & 74 & 24.98 & 334 & 73.89 & 219 & 73.54 \\
\hline Final felling & 7 & 18.92 & 51 & 63.02 & 14 & 37.84 & 70 & 85.56 & 26 & 70.27 & 79 & 96.49 \\
\hline Total subcompartment & 42 & 3.04 & 76 & 6.30 & 122 & 8.82 & 144 & 12.02 & 599 & 43.31 & 697 & 58.03 \\
\hline
\end{tabular}

Table 9. Available amounts of timber and ratio to supply potentials on profitable aggregated stands without subsidy from 2005 to 2010.

\begin{tabular}{|c|c|c|c|c|c|c|}
\hline \multirow[t]{2}{*}{ Unit prices } & \multicolumn{2}{|c|}{3,000 yen/ton } & \multicolumn{2}{|c|}{6,000 yen/ton } & \multicolumn{2}{|c|}{10,000 yen/ton } \\
\hline & Amounts $\left(\mathrm{m}^{3}\right)$ & Ratio (\%) & Amounts $\left(\mathrm{m}^{3}\right)$ & Ratio (\%) & Amounts $\left(\mathrm{m}^{3}\right)$ & Ratio (\%) \\
\hline Precommercial thinning & 0 & 0.00 & 0 & 0.00 & 2,379 & 46.11 \\
\hline Commercial thinning & 634 & 5.12 & 2,777 & 22.44 & 8,802 & 71.13 \\
\hline Final felling & 7,359 & 61.06 & 9,924 & 82.35 & 11,444 & 94.96 \\
\hline Total & 7,992 & 27.01 & 12,700 & 42.93 & 22,625 & 76.47 \\
\hline
\end{tabular}

\subsection{Available Amounts from Profitable Aggregated Stands with Subsidy}

The number and areas of profitable aggregated stands with a 3,000-yen/ton logging residue price and a subsidy were 185 aggregated stands including 601 subcompartments $(43.46 \%)$ and 
Table 10. Available amounts of logging residues and ratio to supply potentials on profitable aggregated stands without subsidy from 2005 to 2010.

\begin{tabular}{lrrrrrr}
\hline Unit prices & \multicolumn{2}{c}{3,000 yen/ton } & \multicolumn{2}{c}{6,000 yen/ton } & \multicolumn{2}{c}{10,000 yen/ton } \\
& Amounts (ton) & Ratio (\%) & Amounts (ton) & Ratio (\%) & Amounts (ton) & Ratio (\%) \\
\hline Precommercial thinning & 0 & 0.00 & 0 & 0.00 & 19,301 & 48.08 \\
Commercial thinning & 537 & 5.17 & 2,323 & 22.38 & 7,664 & 73.86 \\
Final felling & 2,091 & 61.77 & 2,820 & 83.31 & 3,245 & 95.85 \\
\hline Total & 2,628 & 4.93 & 5,143 & 9.64 & 29,940 & 56.13 \\
\hline
\end{tabular}

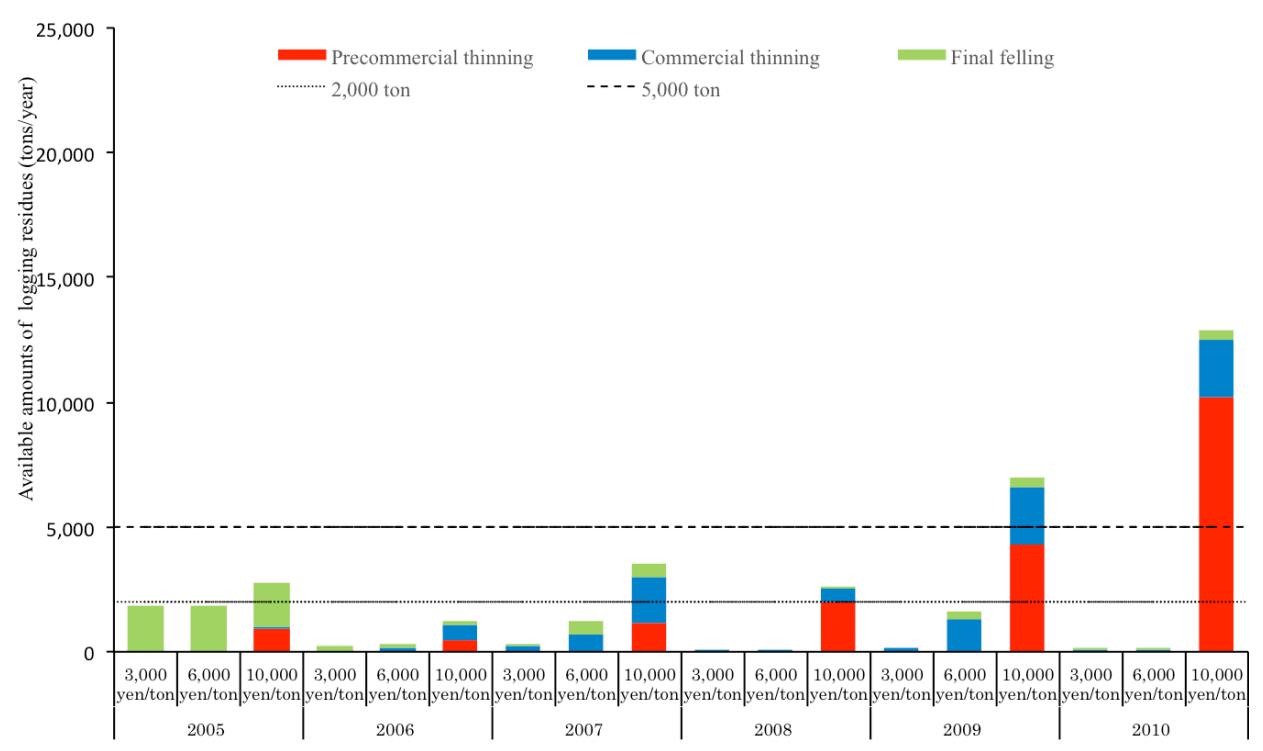

Figure 7. Available amounts of logging residues on profitable aggregated stands without subsidy from 2005 to 2010 .

593 ha $(49.43 \%)$, of which 222 subcompartments $(24.83 \%)$ and 304 ha $(37.03 \%)$ were from precommercial thinning operations, 365 subcompartments $(80.75 \%)$ and 234 ha $(78.71 \%)$ were from commercial thinning operations, and 14 subcompartments $(37.84 \%)$ and 55 ha $(67.27 \%)$ were from final felling operations, respectively (Table 11). The available timber and logging residue amounts from profitable aggregated stands with a 3,000-yen/ton logging residue price and a subsidy were $18,454 \mathrm{~m}^{3}$ and 20,526 tons (3,421 tons/year), of which $8 \%\left(1,399 \mathrm{~m}^{3}\right)$ and $50 \%(10,349$ tons or 1,725 tons/year) were from precommercial thinning operations, $49 \%\left(9,100 \mathrm{~m}^{3}\right)$ and $39 \%(7,922$ tons or 1,320 tons/year) were from commercial thinning operations, and $43 \%\left(7,955 \mathrm{~m}^{3}\right)$ and $11 \%(2,255$ tons or 376 tons/year) were from final felling operations, respectively (Tables 12 and 13, Figure 8 ). The number and areas of profitable aggregated stands and available logging residue amounts were increased with a subsidy. The available logging residue amounts with unit prices of logging residues of $3,000,6,000$, and 10,000 yen/ton were increased to 20,526 tons (3,421 tons/year), 34,981 tons (5,830 tons/year), and 45,175 tons (7,529 tons/year), respectively. The ratios of the available amounts to supply potentials with logging residue unit prices of 3,000, 6,000, and 10,000 yen/ton were also increased to $38.48 \%, 65.57 \%$, and $84.68 \%$, respectively. The increases in logging residue unit prices of $3,000,6,000$, and 10,000 yen/ton were $7.8,6.8$, and 1.5 times the available amounts without a subsidy. 
Table 11. The number and areas of profitable aggregated stands with subsidy from 2005 to 2010.

\begin{tabular}{|c|c|c|c|c|c|c|c|c|c|c|c|c|}
\hline \multirow[t]{2}{*}{ Unit prices } & \multicolumn{4}{|c|}{3,000 yen/ton } & \multicolumn{4}{|c|}{6,000 yen/ton } & \multicolumn{4}{|c|}{10,000 yen/ton } \\
\hline & No. & $\begin{array}{r}\text { Ratio } \\
(\%)\end{array}$ & $\begin{array}{c}\text { Area } \\
\text { (ha) }\end{array}$ & $\begin{array}{r}\text { Ratio } \\
(\%)\end{array}$ & No. & $\begin{array}{r}\text { Ratio } \\
(\%)\end{array}$ & $\begin{array}{c}\text { Area } \\
\text { (ha) }\end{array}$ & $\begin{array}{r}\text { Ratio } \\
(\%)\end{array}$ & No. & $\begin{array}{r}\text { Ratio } \\
(\%)\end{array}$ & $\begin{array}{r}\text { Area } \\
\text { (ha) }\end{array}$ & $\begin{array}{r}\text { Ratio } \\
(\%)\end{array}$ \\
\hline Stand & 185 & 33.04 & 593 & 49.43 & 276 & 49.29 & 837 & 69.75 & 366 & 65.36 & 1,001 & 83.42 \\
\hline Precommercial thinning & 222 & 24.83 & 304 & 37.03 & 443 & 49.55 & 507 & 61.73 & 597 & 66.78 & 650 & 79.23 \\
\hline Commercial thinning & 365 & 80.75 & 234 & 78.71 & 392 & 86.73 & 254 & 85.24 & 414 & 91.59 & 272 & 91.39 \\
\hline Final felling & 14 & 37.84 & 55 & 67.27 & 23 & 62.16 & 77 & 93.88 & 26 & 70.27 & 79 & 96.49 \\
\hline Total subcompartment & 601 & 43.46 & 593 & 49.43 & 858 & 62.04 & 837 & 69.75 & 1,037 & 74.98 & 1,001 & 83.42 \\
\hline
\end{tabular}

Table 12. Available amounts of timber and ratio to supply potentials on profitable aggregated stands with subsidy from 2005 to 2010 .

\begin{tabular}{lrrrrrr}
\hline Unit prices & \multicolumn{2}{c}{3,000 yen/ton } & \multicolumn{2}{c}{6,000 yen/ton } & \multicolumn{2}{c}{10,000 yen/ton } \\
& Amounts $\left(\mathrm{m}^{3}\right)$ & Ratio $(\%)$ & Amounts $\left(\mathrm{m}^{3}\right)$ & Ratio $(\%)$ & Amounts $\left(\mathrm{m}^{3}\right)$ & Ratio $(\%)$ \\
\hline Precommercial thinning & 1,399 & 27.10 & 3,131 & 60.66 & 84,235 & 82.07 \\
Commercial thinning & 9,100 & 73.54 & 10,093 & 81.56 & 11,077 & 89.51 \\
Final felling & 7,955 & 66.01 & 11,217 & 93.07 & 11,444 & 94.96 \\
\hline Total & 18,454 & 62.37 & 24,440 & 82.60 & 26,756 & 90.43 \\
\hline
\end{tabular}

Table 13. Available amounts of logging residues and ratio to supply potentials on profitable aggregated stands with subsidy from 2005 to 2010.

\begin{tabular}{lrrrrrr}
\hline Unit prices & \multicolumn{2}{c}{3,000 yen/ton } & \multicolumn{2}{c}{6,000 yen/ton } & \multicolumn{2}{c}{10,000 yen/ton } \\
& Amounts (ton) & Ratio (\%) & Amounts (ton) & Ratio (\%) & Amounts (ton) & Ratio (\%) \\
\hline Precommercial thinning & 10,349 & 26.14 & 23,039 & 58.20 & 32,581 & 82.31 \\
Commercial thinning & 7,922 & 76.35 & 8,763 & 84.46 & 9,349 & 90.11 \\
Final felling & 2,255 & 66.62 & 3,179 & 93.89 & 3,245 & 95.85 \\
\hline Total & 20,526 & 38.48 & 34,981 & 65.57 & 45,175 & 84.68 \\
\hline
\end{tabular}

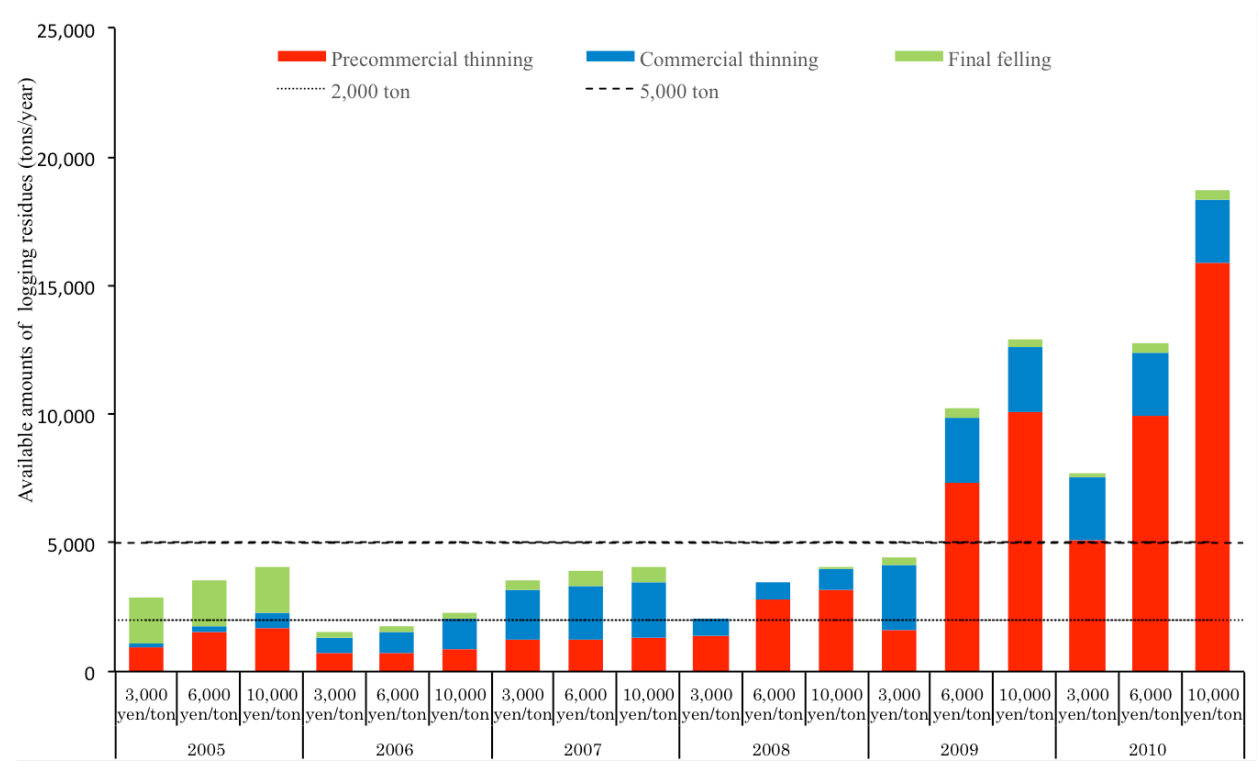

Figure 8. Available amounts of logging residues on profitable aggregated stands with subsidy from 2005 to 2010. 


\section{Conclusions}

In this study, forest management records from 2005 to 2010 were used to estimate and compare supply potentials and available logging residue amounts from profitable aggregated stands from Nasushiobara city in Tochigi prefecture with those from profitable subcompartments. As a result, the available logging residue amounts from commercial thinning operations were increased for aggregated stands. However, the available logging residue amounts from final felling operations were decreased because the profitability of the final felling operations was reduced by aggregating the deficit thinning operations. In this study, aggregating subcompartments decreased indirect costs such as machine transportation expenses and garage-maintenance expenses because such indirect costs were fixed, the larger the volume, the lower the cost. However, aggregating subcompartments would improve operational efficiency and reduce operation costs by establishing road networks and promoting mechanization although this study did not consider. It is difficult to find out increases on operational efficiency and reduction of operation costs by aggregating subcompartments (Aruga et al., 2013a), but the system should be improved to consider this.

Considering the subsidy, the available logging residue amounts were significantly increased, and those with a 3,000-yen/ton logging residue price were 3,421 tons/year over the expected demand of logging residues of 2,000 tons/year. Furthermore, the available logging residue amounts with a 6,000-yen/ton and a 10,000-yen/ton logging residue price were 5,830 tons/year and 7,529 tons/year over the expected demand for woody biomass of 5,000 tons/year. This study estimated the supply potential and availability using forest management records from 2005 to 2010, and examined the trends. As a result, the supply potential and availability of logging residues, particularly from precommercial thinning operations, were significantly increased from 2009 because of the new tax that started in April 2008. The next study will project the supply potentials and available logging residue amounts using forest management plans.

\section{Acknowledgement}

We are grateful to the Tochigi Prefecture Government for providing the required data.

\section{References}

Agency for Natural Resources and Energy (2012) Settlement of the details of the Feed-in Tariff scheme for renewable energy, including purchase price and surcharge rates, $<$ http://www.meti.go. jp/english/press/2012/0618_01.html> (Accessed 18 June 2012).

Aruga, K., Hiyamizu, G., Nakahata, C., and Saito, M. (2013a) Effects of aggregating forests, establishing forest road networks, and mechanization on operational efficiency and costs in a mountainous region in Japan, J. Forestry Res. 24: 747-754.

Aruga, K., Murakami, A., Nakahata, C., Yamaguchi, R., Saito, M., and Kanetsuki, K. (2013b) A model to estimate available timber and forest biomass and reforestation expenses in a mountainous region in Japan, J. Forestry Res. 24: 345-356.

Dijkstra, E.W. (1959) A note on two problems in connection with graphs, Numerische Mathematik 1: 269-271.

Forestry Agency, The Ministry of Agriculture, Forestry and Fisheries of Japan (2013) Annual Report on Forest and Forestry in Japan. Fiscal Year 2012 (summary), Tokyo.

Greenhouse Gas Inventory Office of Japan (2006) Greenhouse Gas Inventory Report in Japan, Tokyo (in Japanese).

Japanese Forestry Investigation Committee (2011a) Tosa No Mori System in which Thinned Trees are Traded with Community Currency for 6,000 yen/ton Begins in Chizu Town, Tottori Prefecture and the System has been Prevailing, *Rinsei (Forest policy*) News 409: 14 (in Japanese).

Japanese Forestry Investigation Committee (2011b) Wood Chip for Power Generation Paid Attention to Feed-in Tariff (FIT), which would Improve the Unit Price of Logging Residue to 20 yen/kWh. 
This Would Promote Effective Utilization of Logging Residues, *Rinsei (Forest policy*) News 405: 7 (in Japanese).

Mikamo Forest Owners' Association and Sumitomo Osaka Cement Company (2008) Research Report on Extracting Forest Biomass Resources, ${ }^{*}$ Mikamo Forest Owners' Association and Sumitomo Osaka Cement Company, Tochigi (in Japanese).

Tochigi Prefectural Government (2010a), Tochigi No Genkina Moridukuri Prefectural Tax (to Make Healthy Forests with Subsidies for Thinning Operations*) Business Evaluation Report of Fiscal Year 2009, Tochigi Prefectural Government, Utsunomiya (in Japanese).

Tochigi Prefectural Government (2010b) Forestation Program Standard Unit Cost Table of Fiscal Year 2010, Tochigi Prefectural Government, Tochigi, 2010 (in Japanese).

Uemura, R., Aruga, K. and Tasaka, T. (2013) Estimating the annual supply potential and availability of timber and logging residue at aggregated stands of Takahara area, Tochigi prefecture, Japan. Proc. IUFRO3.08866.08 Joint Conference in Fukuoka, pp. 435-462.

Yamaguchi, R., Aruga, K. and Nagasaki, M. (2014a) Estimating the annual supply potential and availability of timber and logging residue using the forest management records of the Tochigi prefecture, Japan, J. Forest Res. 19: 22-33.

Yamaguchi, R., Aruga, K., Murakami, A., Nakahata, C., Saito, M. and Nagasaki, M. (2014b) Effects of stand conditions on annual availability of logging residue estimated using forest management records in Tochigi prefecture, Japan, FORMATH 13: 20-40.

Zenkoku Ringyo Kairyo Fukyu Kyokai (2001) Management of Forestry Mechanization, Zenkoku Ringyo Kairyo Fukyu Kyokai, Tokyo (in Japanese).

*Approximate translations by the authors. 